\title{
鼻呼吸時クロージングボリューム
}

*大 越 俊 夫

\section{Study on the Relationship between Nasal Breathing and Closing Volume}

\author{
Toshio Okoshi, M.D.
}

Department of Otorhinolaryngology, Toho University School of Medicine, Tokyo

This study was done in order to determine how nasal obstruction, which can be regarded as a kind of upper airway stenosis, affects closing volume (CV).

Closing volume, measured with oral and nasal respiration, was compared in thirty-two adult patients. In addition, the percent vital capacity (\% VC), percent forced expiratory volume $\left(\% \mathrm{FEV}_{1.0}\right)$, and flow-volume curves were compared.

The results were as follows:

1) When measured by means of oral and nasal respiration there was no significant difference in $\mathrm{CV}$ between the normal subjects group and nasal obstruction group.

2 ) When measured by means of nasal respiratory resistance ( $R r)$, peak flow (PF), maximal expiratory flow at 75 percent $\left(V_{75}\right)$ and 50 percent $\left(V_{50}\right)$ showed a significant difference between the normal subjects group and nasal obstruction group. No significant was difference found, however, at 25 percent $\left(\mathrm{V}_{25}\right)$.

\section{I 緒 言}

換気機能検査の進歩に伴い上気道と下気道と の間の相互関係の分析が可能になってきた。わ れわれは前回までに呼吸抵抗，スパイロメトリ 一1)，フローボリューム曲線2)について検討を 行ない，これらの検查方法に上気道狭窄が種々 の影響を及ぼすことを報告してきた。今回は， 末梢気道閉塞状態を鋭敏に検出するといわれて いるクロージングボリューム検査において，上 気道狭窄状態の一種とみなし得る鼻呼吸がどの ような影響を及ぼすかを検討した。

\section{II 研究方法}

\section{1 対象}

検査対象は18歳から30歳までの平均年齢, 21.7 歳, 平均身長 $161.8 \mathrm{~cm}$ の成人 32 名（男子 16 名, 女子16名）であり，全例に特記すべきアレ ルギー性呼吸器疾患, 心疾患, 肺疾患, 肝疾患

*東邦大学医学部耳鼻咽喉科学教室
などは認められなかった。また，鼻腔抵抗を測 定し得た 17 名を鼻腔抵抗值により, $3.0 \mathrm{~cm} \mathrm{H}_{2} \mathrm{O}$ $/ 1 / \mathrm{sec}$ 末満の正常群 7 例と $3.0 \mathrm{~cm} \mathrm{H} \mathrm{H}_{2} \mathrm{O} / 1 / \mathrm{sec}$ 以上の鼻閉塞群 10 例に分けて検討を行なった。 各々の群の平均年齢, 平均身長は正常群 22.7 歳, $165.3 \mathrm{~cm}$, 鼻閉塞群 21.8 歳, $159.8 \mathrm{~cm}$ であ った。

2 測定器械および測定方法

(1)呼吸抵抗 $(\mathrm{Rr})$

測定には前回と同しく可変型の呼吸抵抗計 （日本光電製 MRP 6 型）を使用し，坐位安静 呼吸にて測定した。

\section{(2)鼻腔抵抗 $(R n)$}

鼻腔抵抗測定には呼吸抵抗測定時に使用した ものと同じ可変型呼吸抵抗計を用いた。すなお ち鼻腔抵抗測定時には Pneumotachometer 部 分をオッシレーション装置より脱却して従来の Pneumotachometer により鼻腔抵抗測定と全 く同じように使用した。測定方法は PosteriorMethod に行なった。 
(3)スパイロメトリーおよびフロー・ボリュー ム曲線 ( $\mathrm{F}-\mathrm{V}$ 曲線)

口呼吸時および鼻呼吸時の\%肺活量 $(\% \mathrm{VC})$, 1 秒率 $\left(\% \mathrm{FEV}_{10}\right)$, 最大呼気速度 (PF または $\dot{\mathrm{V}} \max$.$) および \mathrm{FV}$ 曲線上の75\%肺活量時の流 速 $\left(\dot{\mathrm{V}}_{75}\right), 50 \%$ 時の流速 $\left(\dot{\mathrm{V}}_{50}\right), 25 \%$ 時の流速 $\left(\dot{V}_{25}\right)$ などの測定にはミナト医科学 Autospirometer AS 2300を用い，立位努力性呼気時に測 定した。

(4)クロージングボリューム検査 (CV検查)

CV の測定には Bolus 法と resident gas 法 がある。bolus 法は残気量位にて He. Ar. ${ }^{133} \mathrm{Xe} . \mathrm{SF}_{6}$ などの不活性ガスを吸 入し，次いで air を全肺気量位まで吸 入，これを残気量位まで呼出するに当 たり，呼気量をX軸，指示ガス濃度を Y 軸として $\mathrm{X}$ 一 Yレコーダあるいはオ ッシロスコープ上に記録させるもので ある。一方 resident gas 法では通常 №が指示ガスに用いられる。測定機 械はミナト 医科学製 Autospirometer NA-850を用い，口呼吸時および鼻呼 吸時に測定を行なった。測定方法は被 検者を坐位にしてオートスパイロメー タを通して最大呼気位まで呼出させた 後, 次いでゆっくりと, $(0.3 \mathrm{~L} / \mathrm{sec}$ 前 後) 最大吸気位まで純酸素を吸入さ せ，さらにゆっくりとほぼ同じ要領で 最大呼気位まで呼出させる方である。 残気量位では上部肺と下部肺でそれぞ れの残気量が異なっている（すなわち 窒素量は上部肺に多く，下部肺に少な い)。このような状態で 全肺気量位ま で純酸素を吸いこませると肺局所の窒 素濃度差が形成されるということを利 用したものである ${ }^{3)}$ 。

\section{III 成 績}

全32例中，口呼吸時および鼻呼吸時 に呼気終末で窒素濃度が急激に上昇す る CV現象すなわち第 4 相の出現しな かった例は20例であり,他の 12 例にCV の出現をみた。しかし，12例とも Buist and Ros による №resident gas 法の
標準值 ${ }^{4)}$ の範囲内であり異常值ではなかった。 $\mathrm{CV}$ の出現した12例について口呼吸時と鼻呼吸 時の CV の比較を行なった。各々の変化は図 1 のごとくであり，太線は各々の平均值である。 $\mathrm{CV}$ が鼻呼吸時に 増加したもの 4 例, 減少し たもの 7 例, 変化しなかったもの 1 例であ り, 平均值では有意の差は認めなかった。次に 鼻閉塞の影響をみるために全32例中鼻腔抵抗を 測定し得た 17 例につき，全鼻腔抵抗值 $3.0 \mathrm{~cm}$ $\mathrm{H}_{2} \mathrm{O} / \mathrm{l} / \mathrm{sec}$ 未満の正常群 7 例 $3.0 \mathrm{~cm} \mathrm{H}_{2} \mathrm{O} / \mathrm{l} / \mathrm{sec}$ 以上の鼻閉塞群 10 例に分け CV の変化を検討し

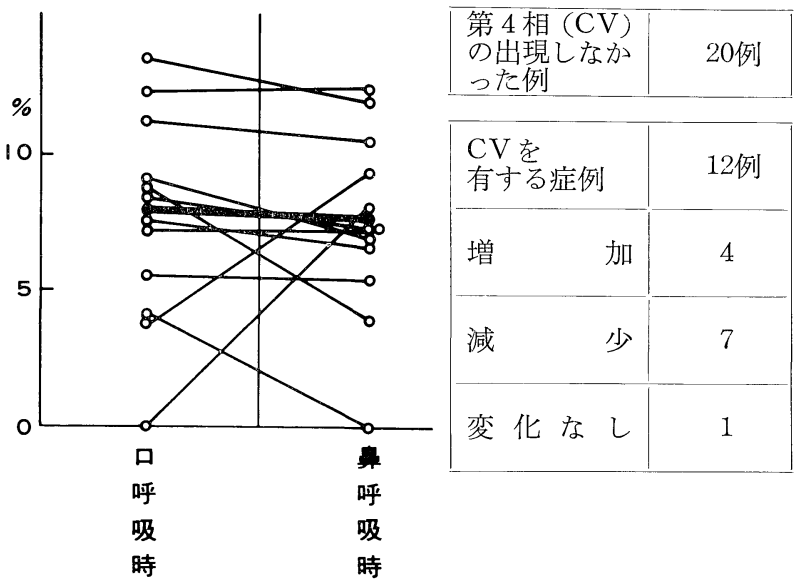

図 1 口呼吸時と鼻呼吸時におけるCV変化(全症例)

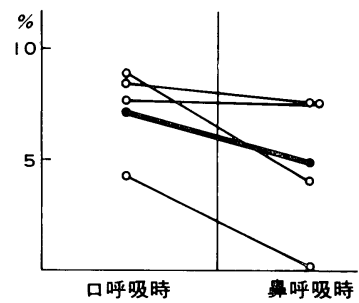

\begin{tabular}{|c|c|c|}
\hline 正 & $\begin{array}{l}\text { 第 } 4 \text { 相 (CV) } \\
\text { の出現しなか } \\
\text { った例 }\end{array}$ & 3 例 \\
\hline \multirow{3}{*}{$\begin{array}{c}\text { 群 } \\
\mathrm{n}=7\end{array}$} & 増 加 & 1 \\
\hline & 減 & 3 \\
\hline & 変 化な し & 0 \\
\hline
\end{tabular}

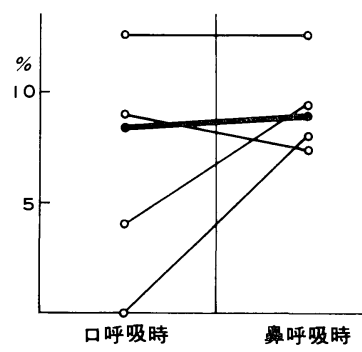

\begin{tabular}{|c|c|c|}
\hline $\begin{array}{l}\text { 鼻 } \\
\text { 閏 }\end{array}$ & $\begin{array}{l}\text { 第 } 4 \text { 相 (CV) } \\
\text { の出現しなか } \\
\text { つた例 }\end{array}$ & 6 例 \\
\hline \multirow{3}{*}{$\begin{array}{l}\text { 塞 } \\
\text { 群 } \\
\mathrm{n}=10\end{array}$} & 増 & 2 \\
\hline & 減 & 1 \\
\hline & 変化なし & 1 \\
\hline
\end{tabular}

図 2 口呼吸時と鼻呼吸時における $\mathrm{CV}$ の変化 （正常群と鼻閉塞群） 
表 1 口呼吸時と鼻呼吸時における各パラメータの平均値と標準偏差

口呼吸時

$\mathrm{n}=32$

\begin{tabular}{|c|c|c|c|c|c|c|c|c|c|}
\hline & $\begin{array}{c}\text { 年 龄 } \\
\text { (歳) }\end{array}$ & $\begin{array}{c}\text { 身 } \\
(\mathrm{cm})\end{array}$ & $\begin{array}{r}\mathrm{Rr} \\
\mathrm{cm} \mathrm{H}_{2} \mathrm{O} / \\
\mathrm{l} / \mathrm{sec}\end{array}$ & $\begin{array}{c}\% \text { VC } \\
(\%)\end{array}$ & $\begin{array}{c}\% \mathrm{FEV} \\
(\%)\end{array}$ & $\begin{array}{c}\dot{\mathrm{V}} \max \\
(\mathrm{l} / \mathrm{sec})\end{array}$ & $\dot{\mathrm{V}}_{75}$ & $\dot{\mathrm{V}}_{50}$ & $\dot{\mathrm{V}}_{25}$ \\
\hline Mean & 21.7 & 161.8 & 2.53 & 99.1 & 90.5 & 7.42 & 7.05 & 4.70 & 2.30 \\
\hline 土 S.D. & 2.61 & 7.93 & 0.85 & 12.9 & 4.61 & 1.92 & 1.81 & 1.10 & 0.57 \\
\hline
\end{tabular}

鼻呼吸時

\begin{tabular}{|c|c|c|c|c|c|c|c|c|c|}
\hline & $\begin{array}{c}\text { 年 齢 } \\
\text { (歳) }\end{array}$ & $\begin{array}{l}\text { 身 長 } \\
(\mathrm{cm})\end{array}$ & $\left(\begin{array}{c}\mathrm{Rr} \\
\mathrm{cm} \mathrm{\textrm {H } _ { 2 } \mathrm { O } /} \\
1 / \mathrm{sec}\end{array}\right)$ & $\begin{array}{c}\% \mathrm{VC} \\
(\%)\end{array}$ & $\begin{array}{c}\% \mathrm{FEV} \\
(\%)\end{array}$ & $\begin{array}{l}\dot{\mathrm{V}} \max \\
(\mathrm{l} / \mathrm{sec})\end{array}$ & $\dot{\mathrm{V}}_{75}$ & $\dot{\mathrm{V}}_{50}$ & $\dot{\mathrm{V}}_{25}$ \\
\hline Mean & & & 5.61 & 94.3 & 78.6 & 3.87 & 3.59 & 3.15 & 2.10 \\
\hline \pm S.D. & & & 1.89 & 12.8 & 12.4 & 1.40 & 1.33 & 1.13 & 0.63 \\
\hline
\end{tabular}

表 2 口呼吸時と鼻呼吸時の各パラメータの有意差の検定

$$
\mathrm{n}=32
$$

\begin{tabular}{|c|c|c|c|c|c|c|c|c|c|}
\hline & $\begin{array}{c}\text { 年 歯 } \\
\text { (歳) }\end{array}$ & $\begin{array}{c}\text { 身 長 } \\
(\mathrm{cm})\end{array}$ & $\begin{array}{r}\mathrm{Rr} \\
\mathrm{cm} \mathrm{H}_{2} \mathrm{O} / \\
\mathrm{l} / \mathrm{sec}\end{array}$ & $\begin{array}{c}\% \text { VC } \\
(\%)\end{array}$ & $\begin{array}{c}\% \mathrm{FEV} \\
(\%)\end{array}$ & $\begin{array}{c}\dot{\mathrm{V}}_{\mathrm{max}} \\
(1 / \mathrm{sec})\end{array}$ & $\dot{\mathrm{V}}_{75}$ & $\dot{\mathrm{V}}_{50}$ & $\dot{\mathrm{V}}_{25}$ \\
\hline 口呼吸時 & 21.7 & 161.8 & 2.53 & 99.1 & 90.5 & 7.42 & 7.05 & 4.70 & 2.30 \\
\hline 鼻呼吸時 & & & 5.61 & 94.3 & 78.6 & 3.87 & 3.59 & 3.15 & 2.10 \\
\hline $\mathrm{P}$ & & & $<0.001$ & $\mathrm{~N} \mathrm{~S}$ & $<0.001$ & $<0.001$ & $<0.001$ & $<0.001$ & $\mathrm{~N} \mathrm{~S}$ \\
\hline
\end{tabular}

\section{表 3 正常群における口呼吸時と鼻呼吸時の比較}

口呼吸時

$\mathrm{n}=7$

\begin{tabular}{|c|c|c|c|c|c|c|c|c|c|}
\hline & $\begin{array}{l}\text { 年 齢 } \\
\text { (歳) }\end{array}$ & $\begin{array}{c}\text { 身 長 } \\
(\mathrm{cm})\end{array}$ & $\left(\begin{array}{c}\mathrm{Rr} \\
\mathrm{cm}_{-} \mathrm{H}_{2} \mathrm{O} / \\
1 / \mathrm{sec}\end{array}\right)$ & $\begin{array}{c}\% \mathrm{VC} \\
(\%)\end{array}$ & $\begin{array}{c}\% \mathrm{FEV} \\
(\%)\end{array}$ & $\begin{array}{l}\dot{V} \max \\
(1 / \mathrm{sec})\end{array}$ & $\dot{\mathrm{V}}_{75}$ & $\dot{\mathrm{V}}_{50}$ & $\dot{\mathrm{V}}_{25}$ \\
\hline Mean & 22.7 & 165.3 & 2.34 & 106.7 & 87.7 & 7.89 & 7.52 & 4.33 & 2. 16 \\
\hline \pm S.D. & 3.55 & 7.91 & 0.62 & 15.3 & 4.23 & 2.16 & 1.91 & 0.95 & 0.57 \\
\hline
\end{tabular}

鼻呼吸時

\begin{tabular}{|c|c|c|c|c|c|c|c|}
\hline Mean & 4.13 & 102.4 & 86.1 & 5. 38 & 5.04 & 4.13 & 2.32 \\
\hline \pm S.D. & 1.45 & 17.2 & 6.07 & 1.45 & 1.31 & 1.01 & 0.52 \\
\hline
\end{tabular}

口呼吸時と鼻呼吸時の比較

\begin{tabular}{|c|c|c|c|c|c|c|c|}
\hline $\mathrm{P}$ & $<0.05$ & N S & N S & $<0.05$ & $<0.05$ & N S & NS \\
\hline
\end{tabular}


日気食会報, $31 （ 5), 1980$

表 4 鼻閉塞群における口呼吸時と鼻呼吸時の比較

口呼吸時

$\mathrm{n}=10$

\begin{tabular}{|c|c|c|c|c|c|c|c|c|c|}
\hline & $\begin{array}{l}\text { 年 齢 } \\
\text { (歳) }\end{array}$ & $\begin{array}{c}\text { 身 長 } \\
(\mathrm{cm})\end{array}$ & $\left(\begin{array}{c}\mathrm{Rr} \\
\mathrm{cm} \mathrm{H} \mathrm{H}_{2} \mathrm{O} / \\
1 / \mathrm{sec}\end{array}\right)$ & $\begin{array}{c}\% \mathrm{VC} \\
(\%)\end{array}$ & $\begin{array}{c}\% \mathrm{FEV} \\
(\%)\end{array}$ & $\begin{array}{l}\dot{\mathrm{V} \max } \\
(1 / \mathrm{sec})\end{array}$ & $\dot{\mathrm{V}}_{75}$ & $\dot{\mathrm{V}}_{50}$ & $\dot{\mathrm{V}}_{25}$ \\
\hline Mean & 21.8 & 159.8 & 2.73 & 97.2 & 92.3 & 6.94 & 6.62 & 4.75 & 2.39 \\
\hline \pm S.D. & 2.10 & 6.89 & 0.76 & 12.0 & 4.11 & 1.68 & 1.67 & 1.13 & 0.65 \\
\hline
\end{tabular}

鼻呼吸時

\begin{tabular}{|l|l|l|l|l|l|l|l|l|}
\hline Mean & & 6.95 & 94.0 & 75.0 & 3.21 & 3.03 & 2.17 & 1.90 \\
\hline 土S.D. & & 1.92 & 10.7 & 9.73 & 0.99 & 1.02 & 0.98 & 0.56 \\
\hline
\end{tabular}

口呼吸時と鼻呼吸時の比較

\begin{tabular}{|c|c|c|c|c|c|c|c|}
\hline $\mathrm{P}$ & $<0.001$ & N S & $<0.001$ & $<0.001$ & $<0.001$ & $<0.001$ & NS \\
\hline
\end{tabular}

た。

正常群（図 2 , 上段）では CV の出現しなか ったもの 3 例，鼻呼吸時に増加したもの 1 例， 減少したもの 3 例であった。鼻閉塞群（図 2 , 下段）では $\mathrm{CV}$ の出現しなかったもの 6 例, 増 加 2 例, 減少 1 例, 不変 1 例であった。

次に同時に測定した呼吸抵抗，スパイロメト リー, F-V 曲線について検討した。

表 1 は全32例における各パラメータの平均值 である。CV と同様に口呼吸時と鼻呼吸時の比 較を行なってみると，呼吸抵抗，1秒率，F-V 曲線上の $\dot{\mathrm{V}} \max , \dot{\mathrm{V}}_{75}, \dot{\mathrm{V}}_{50}$ にて 有意差 $(\mathrm{P}<$ $0.001)$ を認めた。しかし $\dot{V}_{95}$ にては有意差を 認めなかった (表 2 )。また正常群と鼻閉塞群 に分け，それぞれにおける口呼吸時と鼻呼吸時 の比較を行なってみると, 正常群では呼吸抵 抗, $\dot{\mathrm{V}} \max , \dot{\mathrm{V}}_{75}$ に有意差 $(\mathrm{P}<0.05)$ を認め, 鼻閉塞群にてはさらに 1 秒率， $\dot{\mathrm{V}}_{50}$ にまでも有 意差 $(P<0.001)$ を認めた。しかし両群とも $\dot{\mathrm{V}}_{25}$ には有意差を認めなかった。図 3 注鼻腔抵 抗 $2.6 \mathrm{~cm} \mathrm{H} \mathrm{H}_{2} \mathrm{O} / \mathrm{l} / \mathrm{sec}$ の正常群に属する例の換気 機能検査成績である。口呼吸時と鼻呼吸時の呼 吸抵抗はおの抒の $2.0 \mathrm{~cm} \mathrm{H} \mathrm{H}_{2} \mathrm{O} / \mathrm{l} / \mathrm{sec}$ と $5.0 \mathrm{~cm}$ $\mathrm{H}_{2} \mathrm{O} / \mathrm{l} / \mathrm{sec}$ であった。\% VC は口呼吸時と鼻呼 吸時では大差なく, CV はともに0\%であっ た。口呼吸時の F-V 曲線は 正常パターンをと もにしているが，鼻呼吸時においてはPF の低 下とそれにつづく effort dependent 部分の特
徵的なプラトーの形成が みられ， $\dot{V}_{50}$ の時点で 口呼吸時の F-V 曲線と一致した。図 4 は鼻腔 抵抗 $40 \mathrm{~cm} \mathrm{H}_{2} \mathrm{O} / \mathrm{l} / \mathrm{sec}$ の鼻閉塞群に 属する 症例 である。ＶVCは口呼吸時と鼻呼吸時では差が なく，また CV もともに $12.5 \%$ あったた F-V 曲線は正常群の場合よりも平低下が著明であ り, 口呼吸時と鼻呼吸時のループの一致は $\dot{\mathrm{V}}_{25}$ の時点まで延長していた。

\section{IV 考 按}

近年, 気道閉塞状態を客観的にとらえようと する試みが諸家によって行なわれ，種々の検査 法が行なわれている。今回, われわれは末梢気 道の閉塞がどの程度存在するかを簡単に知るこ とができ，しかも肺容量との関係で数量的に表 わせるといわれているクロージングボリューム に鼻閉塞がどのような影響を及ぼすかを検討し た。

1967年 Dollfuss ${ }^{5)}$ 1968年 Holland ${ }^{6)}$ は ${ }^{133} \mathrm{Xe}$ Bolus の単一呼気濃度で ${ }^{133} \mathrm{Xe}$ の濃度が急激に 上昇してくる部分のあることを認め, この肺気 量を closing volume (CV) と名付けた。Dollfuss らは残気量位 (RV) から全肺気量位 ( $T$ LC) 近くの高肺気量位に至る間の種々の肺気 量位に掞いて $1 \mathrm{ml}$ の ${ }^{133} \mathrm{Xe}$ を注入した後, $\mathrm{TL}$ Cまで空気を吸入させ，ゆっくり呼出を行なっ た際の呼気中の ${ }^{133} \mathrm{Xe}$ 濃度の变化を検討した。 縦軸（Y軸）に口元での ${ }^{133} \mathrm{Xe}$ 濃度をとり，横 
PULMONARY FUNCTION REPORT

NAME : 佐 $\bigcirc$ 行 $\bigcirc$

SEX : $\quad M$

CHART NO.

DATE :

AGE : 21

$\mathrm{Ht}: 168 \mathrm{~cm} \quad \mathrm{Wt}: 58 \mathrm{~kg}$

Flow-Volume Loop :

I

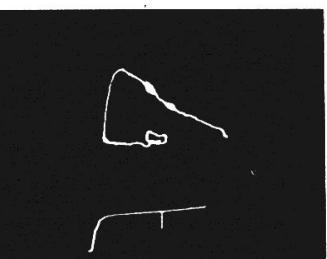

I

$$
\begin{aligned}
& \dot{\mathrm{V}}_{75}=8.451 / \mathrm{sec} \\
& \dot{\mathrm{V}}_{50}=4.80 \mathrm{\prime \prime} \\
& \dot{\mathrm{V}}_{25}=2.70 \mathrm{\prime \prime}
\end{aligned}
$$

Spirometric data:

I II

VC :

VCpred: 4.30

\% VC: 106.0

FVC:

4. 60

104.4

FEV :

4. 10

$\mathrm{FEV}_{10} \%: 89$

PEF :

9.25

4.50

3.87

86

Closing volume: $\frac{\mathrm{CV}}{\mathrm{VC}} \%=0$
II

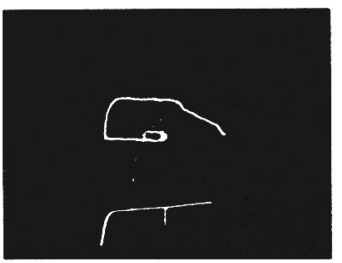

II

$$
\begin{aligned}
& \dot{\mathrm{V}}_{75}=5.00 \mathrm{l} / \mathrm{sec} \\
& \dot{\mathrm{V}}_{50}=4.90 \mathrm{\prime \prime} \\
& \dot{\mathrm{V}}_{25}=2.80 \mathrm{\prime \prime}
\end{aligned}
$$

Air flow resistance $\left(\mathrm{cm} \mathrm{H}_{2} \mathrm{O} / \mathrm{l} / \mathrm{sec}\right)$ : through Mouth through Nose

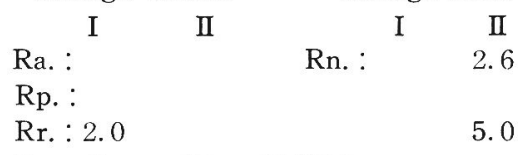

Compliance $\left(1 / \mathrm{cm} \mathrm{H}_{2} \mathrm{O}\right)$ :

Specific compliance :

FRC (ml)

図3正常例

\section{PULMONARY FUNCTION REPORT}

NAME: 鈴 $\bigcirc$ 純 $\bigcirc$

DATE :

Flow-Volume Loop:

I

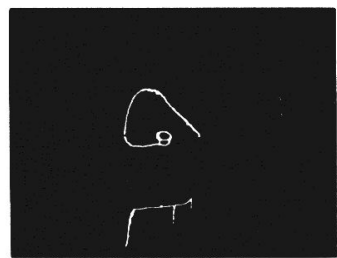

I

$$
\begin{aligned}
& \dot{\mathrm{V}}_{75}=5.851 / \mathrm{sec} \\
& \dot{\mathrm{V}}_{50}=5.30 \prime \prime \\
& \dot{\mathrm{V}}_{25}=2.55 \prime \prime
\end{aligned}
$$

Spirometric data :

$\begin{array}{lcc} & \text { I } & \text { II } \\ \text { VC : } & & \\ \text { VCpred : } & 2.32 & \\ \text { \% VC : } & 122 & 117 \\ \text { FVC : } & 2.85 & 2.72 \\ \text { FEV : } & 2.75 & 2.40 \\ \text { FEV } 10 \%: & 96 & 88 \\ \text { PEF : } & 6.00 & 2.80\end{array}$

Closing volume : $\frac{\mathrm{CV}}{\mathrm{VC}} \%=12.5$
SEX : $\quad F$

AGE : 21

\begin{tabular}{|c|c|c|c|}
\hline I & II & & II \\
\hline Ra.: & & Rn. : & 4.0 \\
\hline Rp. : & & & \\
\hline Rr.: 2.8 & & & 6.0 \\
\hline
\end{tabular}

CHART NO.

Ht : $151 \mathrm{~cm} \quad$ Wt $: 44 \mathrm{~kg}$
II

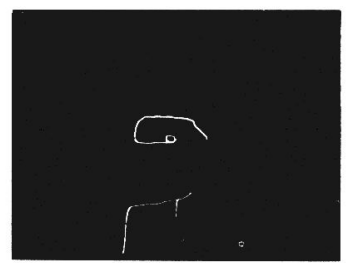

II

$$
\begin{aligned}
& \dot{\mathrm{V}}_{75}=2.70 \mathrm{l} / \mathrm{sec} \\
& \dot{\mathrm{V}}_{50}=2.70 \mathrm{\prime \prime} \\
& \dot{\mathrm{V}}_{25}=2.40 \mathrm{\prime \prime}
\end{aligned}
$$

Air flow resistance $\left(\mathrm{cm} \mathrm{H}_{2} \mathrm{O} / \mathrm{l} / \mathrm{sec}\right.$ ) through Mouth through Nose

Compliance $\left(1 / \mathrm{cm} \mathrm{H}_{2} \mathrm{O}\right)$ :

Specific compliance :

FRC (nl) :

図 4 鼻. 閉塞症例 
軸 (X軸) に呼出肺気量をとって両 者の関係をみると図 5 のごとくなる

(Xe 単一呼出曲線)。この曲線は 3 力所で濃度が急激に変化している。

Dollfuss らはその各部を第 1 相 (Phase I) 〜第 4 相 (Phase IV) と命 名した。第 1 相は呼気開始後 0.1 0.21 を呼出した時期のもので ${ }^{133} \mathrm{Xe}$ は含まれず, 器具および大気 道の死腔ガスよりなっている。第 2 相は ${ }^{133} \mathrm{Xe}$ が急激に上昇してくる部 分で第 1 相後の $0.1 \sim 0.21$ の呼気 よりなる。ここでは死腔ガスと肺胞 ガスが入りまじり，後者がしだいに 増してくる部分である。第 3 相はそ の後につづく肺活量（V C） 70〜 80\%にわたってみられる徐々に上昇 するプラトーの部分である。いわゆ る alveolar Pletteau と呼ばれるも ので，これに重なって心搏動に一致 した周期性の搏動波がみられる。こ の波を Cardiogenic osscillation と いら。さらに呼期終末に近づくにつ れてプラトーが急激に上昇し Cardiogenic osscillation が消失する。 このような終末部の変化を第 4 相と 名付けた。

現在では CV は第 4 相のはじめか ら RV までの肺活量を指して $\mathrm{CV}+$ RV i closing capacity (CC) と 呼ばれている。

CV が出現するといらことは呼気 中の $\mathrm{N}_{2}$ ガス濃度が呼気終末の近く で急に上昇するといらことを示して いるが，これ㐫る程度以上に呼出させると下 部肺に気道閉塞がおこり，それ以上の肺気量の 減少がおこらなくなるため，それ以後は上の方 の肺からだけ呼出が行なわれることによる。つ まり肺低部より気道の閉塞がおこるので，下部 肺に気道閉塞がおこると低肺気量位で呼気の大 部分が急に窒素ガス濃度の高い上部肺からのも のにかわることを示すものである7 。

今回の研究にて CV の出現した例は32例中12 例であり，20例においては口呼吸時, 鼻呼吸時

\section{Xenon conc.} counts $/ 0.05$ sec

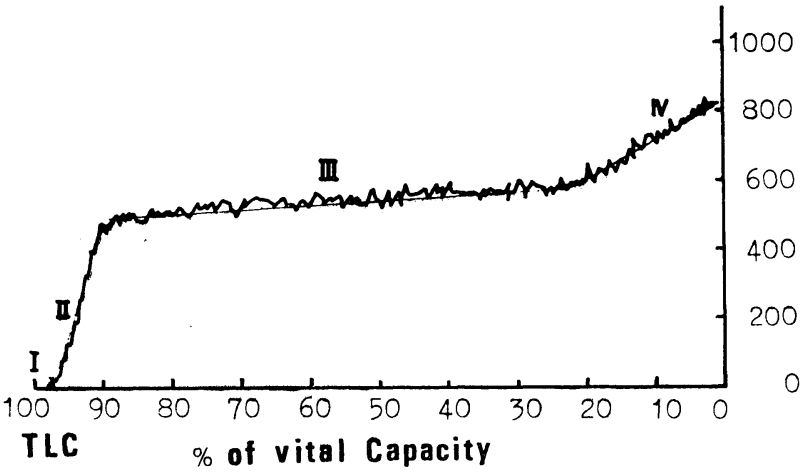

縦軸は xenon 濃度を横軸は呼出肺気量を示す。呼気終末に急 激な濃度上昇を呈する第 4 相がみられる。記録にみられる基線 の動摇は放射能カウントのバラツキによる人為的なものであ る。(Dollfuss 他 ${ }^{5)}$ )

図 5

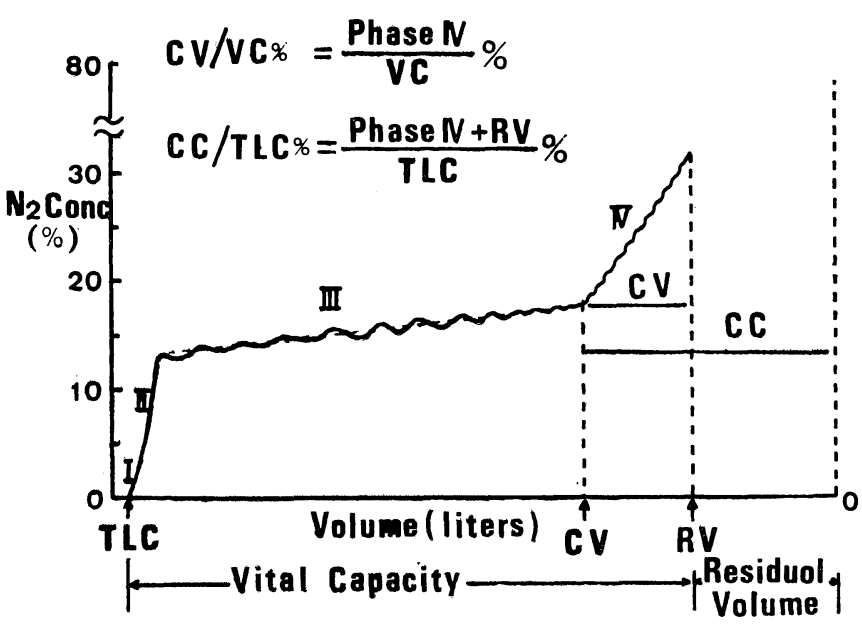

$\mathrm{CV}$ のトレーシングの1例と分析法を示したもの

(Buist (他)

図 6 クロージングボリューム（CV) とクロージン グキャパシティー（CＣ）測定法

ともに，CV の出現はみなかった。 $\mathrm{CV}$ の出現 した12例では鼻呼吸時に増加したものも減少し たものも有り，とくに一定した傾向は認められ なかった。また，鼻閉塞の程度により正常群，

鼻閉塞群に分け，各々のCVを比較したが，こ の場合にも CV にとくに変化はなかった。よっ てロ呼吸時でも鼻呼吸時でも，また鼻閉の有無 に関係なく, CV 出現には変化がないものと思 われた。

次に CVの著明に変化した例を検討してみる 
と下記の問題点があった。

(1) $\mathrm{CV}=\mathrm{VC} / \mathrm{CV} \%$ として表現するので口呼吸 時と鼻呼吸時の VC が著しく差がある場合には $\mathrm{CV}$ の值も当然著しく異なってくる。われわれ の前回の報告にもあるように, 両側性の強度の 鼻閉でないかぎり，口呼吸時でも鼻呼吸時でも VCには大差がないはずなので, 今回はVCが両 者の間に10\%以上の差がある症例は除外した。

(2)鼻閉が両側性であり，かつ強度の場合には 十分な呼吸が行なえず, 鼻呼吸時の CV 測定が 困難な場合がある。

(3) CV 曲線の第 3 相より第 4 相への移行部が 明瞭でないため CV の計測困難な症 例があっ た。この場合呼出速度が問題と思われた。

(4)測定時の実際上の問題点としては, 鼻呼吸 時の際に使用する顔面マスクよりの呼気のもれ があると CV 曲線の終末部分が描記されてこな いので，この点にも十分な注意を要するものと 思われる。

なお，CVに影響を及ぼす因子としては諸家 により種々の因子が挙げられている。

(1) 個人的因子

年齢 ${ }^{899)}$, 喫煙 ${ }^{10)}$, 肥満 ${ }^{11)}$, 妊娠など

(2)測定法の因子

指示ガスの種類, 体位, 呼気速度, 吸気速度 など

また，CV の増加する疾患としては慢性気管 支炎, 肺気腫, 肺線維症などの smoll airway disease を生じる肺疾患や左心不全, 肝硬変症 などがある。なお，H.D鼻アレルギー患者にお いてもクロージングボリュームが増加するとい われている7。

われわれは鼻閉塞が種々の換気機能検查に及 ぼす影響を検討してきたが，スパイロメトリー や F-V 曲線, 呼吸抵抗などの検査法では少な からず上気道狭窄の影響を受けるものである。 これに対して, CV 検査法は上気道狭窄の影響 を受けない検查法であるといらことが実証され た。最近, 下気道の閉塞性疾患注対する換気力 学的検查や換気機能検查成績によるパターン化 が進んできているが，上気道狭窄に対するパタ ーン化がなおまだ一般的には確立されていない 現在，上気道狭窄の影響を受けない $\mathrm{CV}$ 検査は 閉塞性気道病変の部位診断や未梢気道部の病変
の程度を知る上で有用な検査法である。

\section{$\mathrm{V}$ 結 語}

成人被検者 32 名について窒素レジデント・ガ ス法により口呼吸時および鼻呼吸時における C $\mathrm{V}$ を測定し比較検討した。また，17名について は鼻腔抵抗 $3.0 \mathrm{~cm} \mathrm{H} \mathrm{H}_{2} \mathrm{O} / 1 / \mathrm{sec}$ を基準にして正常 群と鼻閉塞群の 2 群に分け比較検討した。その 結果

(1) 口呼吸時, 鼻呼吸時の両方において鼻閉塞の 有無にかかわらず CV は有意の差を認めなかっ た。

(2) $\mathrm{CV}$ 検查法は上気道狭窄の影響を受けない未 梢気道の状態のみを表わす検査法である。

稿を終るに臨み直接御指導を受けた田井信郎助教 授に深謝いたします。

本研究の一部は昭和53年度文部省科学研究費奖励 研究の援助を受けた。記して謝意を表す。本論文の 要旨㳊第30回日本気管食道科学会総会にて発表し た。

\section{参考文献}

1) 大越俊夫：鼻閉塞と掺気機能, 耳鼻展, 20 (補 3 ) : 115-121, 1977.

2 ) 大越俊夫：鼻閉塞とフロー・ボリューム曲線, 耳鼻展, 21 (補 3)：45-53, 1978.

3) 佐々木孝夫：Closing volume, 呼と循, 22 : 724-730, 1974.

4 ) Buist, A.S. and Ross, B.B.: Predicted values for closing volume using a modified single breath nitrogen test. Am. Rev. Resp. Dis., $107:$ 744-752, 1973.

5 ) Dollfuss, R.E. et al.: Regional ventilation of the lung studied with Doluses of ${ }^{133} \mathrm{Xe}$. Resp. Physiol., 2 : 234-246, 1967.

6) Holland, J. et al.: Regional distribution of pulmonary ventilation and perfusion in elderly subjects. J. clin, Invest., $47:$ 81-92, 1968.

7 ) 白井信郎 : HD. 鼻アレルギーのクロージングボ リューム, 耳鼻展, 21 (補 3 ) : 191-200, 1978.

8) Lebranc, P., Ruffu, F.: Effects of age and body position on "airway closure" in man. J. APPI Physiol., $28: 448-451,1970$.

9 ) Mansell, A., Bryan, C.: Airway closure in children. J. APPI, Physiol., 33 : 711-714, 1972.

10) Hoppner, V.H., Cooper, D.M.: Relationship between elastic recoid and closing volume in smokers and nonsmokers. Am. Rev. Resp. Dis., $109: 81-86,1974$.

11) Collins, J.V.: Closing volume-a test of small airway function? Brit. J. Dis. Chest, $67: 1-18$, 
1973.

12) Green, M., Travis, D.M.: A simple measurement of phase IV using a critical ortica. relcum. analyser. J. Apple. Physiol., 32 : 827830, 1972.

13) Millite, B., Robertson, P.C.: Effect of expiratory flow rate on emptying of the regions. J. Apple. Physiol., 27 : 587-581, 1969.

14) Robertson, P.C., Anthoniesen, N.R.,: Effect of inspiratory flow rate on regional distribution of inspired gas. J. Apple. Physiol., 26 : 438-443, 1969.

(別刷請求：=143 東京都大田区大森西6-11-1 東邦大学医学部耳鼻咽喉科学教室 大越 俊夫

（投稿受付 1980 年 3 月 17 日） 